https://doi.org/10.18485/kud_kiaz.2019.ch36

\author{
Агиль Шахмурадов \\ Доктор философии по истории \\ Азербайджанский Университет Языков
}

\title{
ПРАВОСЛАВНАЯ ОБЩИНА АЗЕРБАЙДЖАНА
}

\begin{abstract}
SUMMARY
Christianity in Azerbaijan has an ancient history, the Orthodox Church plays an important role in the religious life of the republic. In 1919, the Baku and Caspian diocese was created, and in 1934 the Soviet government decided to close this diocese. It was restored in 1998 and now 5 Orthodox churches are functioning in Azerbaijan. At present, the Orthodox Christians of Azerbaijan freely perform their rites and traditions and take an active part in the public life of the republic.
\end{abstract}

Key words: Azerbaijan, Christianity, Orthodoxy, Diocese, temple.

Исторические земли Азербайджана, на которых традиции государственности формировались с древнейших времен, является местом, где проходили интенсивные этнические и религиозные процессы. Азербайджан, который является мостом между Востоком и Западом, находится на стыке христианского и исламского миров, на перекрестке важных торговых и коммуникационных путей, привлекает к себе внимание тем, что здесь имеют место устойчивые контакты между различными этническими группами и народами, диалог между различными религиями, мирно сосуществуют ислам, христианство и иудаизм. Эта особенность является одним из факторов, определяющих место и роль Азербайджана в системе международных отношений. 
Развитие диалога между цивилизациями, культурами и конфессиями является одним из основных приоритетов современной эпохи, одним из факторов, которые могут обеспечить глобальную и региональную безопасность. Азербайджан занимает особое место среди стран, где существуют межрелигиозный и межкультурный диалог, межконфессиональное согласие и толерантность.

Межрелигиозный диалог и религиозная терпимость, имевшие место в Азербайджане, является достойным ответом тем, кто утверждает, что будущее человечества нацелено не на диалог, а на религиозную конфронтацию. По словам одного из авторов идеи «столкновение цивилизаций», С. Хантингтона, после окончания «холодной войны» страны объединятся не на основе универсальных ценностей, а на основе цивилизаций, к которым они принадлежат: «Возникает мировой порядок, основанный на цивилизациях: общества, имеющие культурные сходства, сотрудничают друг с другом; попытки переноса обществ из одной цивилизации в другую оказываются бесплодными; страны группируются вокруг ведущих или стержневых стран своих цивилизаций» [1, с. 15].

С. Хантингтон, который предполагает, что вероятность конфликта между мусульманами и немусульманами возрастает, включает Кавказ в число регионов, где существует вероятность конфликта между цивилизациями: «Кровавые столкновения цивилизаций в Боснии, на Кавказе, Центральной Азии или в Кашмире могут разрастись в большие войны» [1, с. 24]. Основываясь на опыте Азербайджана, где люди, принадлежащие к разным цивилизациям - исламской, христианской, иудейской - веками мирно живут бок о бок, на содержании, ценностях и принципах упомянутых религий, можно утверждать, что в настоящем времени не существуют серьезных и объективных причин для конфликта между цивилизациями.

Хотя исламская религия и культура широко распространены по всему Азербайджану, здесь также суще- 
ствуют и действуют свободно христианские и иудейские общины. Во время своего официального визита в Азербайджан в 2002 году Папа Иоанн Павел II заявил, что «Богатая разнообразием и кавказскими чертами, эта страна вобрала в себя достояния многих культур, в особенности, персидской и алтайско-туранской. На этой земле были и по сей день присутствуют крупные религии: зороастризм сосуществовал с христианством албанской Церкви, игравшей столь важную роль в древности. Впоследствии ислам играл все более растущую роль, и в наши дни он является религией подавляющего большинства азербайджанского народа. Свой неповторимый вклад с незапамятных времен внес и иудаизм, до сих пор пользующийся высокой оценкой. Даже после ослабления первоначального блеска Церкви христиане продолжали жить бок о бок с верующими других религий. Это стало возможным благодаря духу терпимости и взаимоприятия, которым нельзя не гордиться этой стране» [2].

Меры, принимаемые государством играют важную роль в сохранении толерантной атмосферы, межконфессионального согласия и диалога в Азербайджане. В 1992 году Милли Меджлис Азербайджана принял Закон «О свободе вероисповедания» [3]. Первая статья закона гласит: «Каждый вправеисповедовать индивидуально или совместно с другими любую религию, выражать и распространять свои убеждения в связи с отношением к религии. Нельзя чинить какие бы то ни было препятствия выражению лицом своего вероисповедования, его участию в богослужении, религиозных обрядах и церемониях или изучению религии. Никто не может быть принужден к выражению (демонстрации) своего вероисповедания, исполнению религиозных церемоний или участию в них...».

С 2001 года в Азербайджане действует Государственный Комитет по Работе с Религиозными Образованиями [4]. В обязанности данного Комитета входит «оказание 
помощи укреплению взаимопонимания между религиозными структурами различных религий, терпимости и уважения друг к другу, предотвращение случаев дискриминации и противостояния на религиозной почве, других негативных явлений».

В настоящее время в Азербайджане официально зарегистрировано 909 религиозных общин, из них 877 исламские, 21 христианские, 8 еврейские, 2 бахаи и 1 общество Кришны. В республике функционируют 2250 мечетей, 14 церквей и 7 синагог. Кроме того, в Азербайджане имеются 10 религиозных учебных заведений [4].

Христианство в Азербайджане имеет многовековую историю. Еще в начале IV века христианство стало государственной религией Кавказской Албании. Несмотря на широкое распространение ислама и ослабление позиций христианства в VII-VIII веках на территории Азербайджана, независимая Албанская церковь сохранила свое существование вплоть до 30-х годов XIX века. Российская империя, которая в первые десятилетия указанного столетия оккупировала северные земли Азербайджана и проводила в регионе проармянскую политику, в 1836 году отменила независимость Албанской церкви и действуя целенаправленно, подчинила христиан-албанцев армянской григорианской церкви.

После захвата северных территорий Азербайджана российское правительство, в целях создания для себя социальную базу, последовательно и целенаправленно проводило здесь политику переселения, иподавляющее большинство переселенцев были православными христианами.

Православная ветвь христианства занимает важное место в религиозной жизни Азербайджана. Как результат распространения здесь православия, в 1815 году в Баку была построена первая православная церковь. В 30-40-х годах XIX века в Азербайджане возникли первые поселения русских православных христиан. Жителями этих деревень были христиане-сектанты, выселенные сюда из 
российских губерний после раскола внутри Русской Православной Церкви. В 1834 году они основали селение Алтыагач в Шемахинском уезде, в 1838 году - селение Вель в Ленкоранском уезде, в 1842 году - селение Русские Борисы, а в 1844 году - селение Славянка в Елизаветпольской губернии. В 1868 году в Бакинской губернии насчитывалось 21 селение, в которых проживали 13 тысяч русских религиозных сектантов [5, с. 153-154]. Переселенческая политика царского правительства в Азербайджане продолжалась и в начале XX века.

В последние десятилетия XIX - начале XX века, в результате социально-экономического развития Северного Азербайджана, развития нефтяной промышленности на Апшеронском полуострове, тысячи выходцев из разных частей Российской империи переселились сюда в поисках работы. В тот период неуклонно росло число людей, работающих в нефтедобывающей, нефтеперерабатывающей, химической, машиностроительной, легкой и пищевой промышленности, в сфере производства строительных материалов. Удельный вес православных в составе рабочих-переселенцев был довольно высоким. Например, в 70-80-х годах XIX века абсолютное большинство владельцев бондарных цехов, занимающихся производством бочек, используемых при перевозке нефти в Бакинском нефтяном регионе, были выходцы из Рязанской, Тамбовской, Симбирской, Владимирской и других губерний. В источниках встречаются имена более 80 таких предпринимателей, и на их предприятиях работали от 5 до 25 человек [6]. Следует отметить, что, использование трубопроводов для транспортировки нефти в последующие десятилетия привело к упадку бондарных цехов, однако православные русские, работавшие в этих цехах, не вернулись на родину, а поселились здесь и продолжили свое участие в экономической, социально-политической и культурной жизни Азербайджана.

В результате увеличения числа православных Русская Православная Церковь расширила свою деятель- 
ность в Азербайджане. В 1905 году была учреждена Бакинская епархия для регулирования религиозной жизни православного населения [7]. В целом, в начале XX века в Азербайджане насчитывалось 70 православных храмов, 17 из которых находились в Баку. Впоследствии приходы по западному побережью Каспийского моря были включены в состав Бакинской епархии, а в 1919 году была создана Бакинская и Прикаспийская епархия [8].

Установление советской власти в Азербайджане в 1920 году характеризовалось началом гонений и репрессий против религии и духовенства. К этому времени 14 из 17 православных храмов в Баку были разрушены [7]. После смерти последнего бакинского епископа Митрофана (Поликарпова) в 1934 г. Бакинская и Прикаспийская епархия прекратила свою деятельность [8]. Однако, несмотря на жесткие меры, предпринятые советским правительством, не получилось полностью вытеснить религию из жизни общества. Население продолжало тайно практиковать свои религиозные ритуалы и обряды.

Во время Второй мировой войны советское правительство решило воспользоваться услугами духовенства для смягчения негативного психологического воздействия войны на население и тогда же православный церковь начала возобновлять свою деятельность в Азербайджане. В 1944 году в Азербайджане и Дагестане были вновь открыты православные церкви, которые вошли в состав Ставропольско-Бакинской епархии Русской Православной Церкви [8]. В 1946 году в городе Хачмас была построена новая церковь [7].

В то же время следует отметить, что в советское время тысячи выходцев из России, Украины и других республик бывшего СССР и принадлежащих к православному христианству, были вовлечены в реализацию крупных экономических проектов в Азербайджане. Это, в свою очередь, оказало значительное влияние на расширение православной общины в Азербайджане. 
После распада СССР и восстановления государственной независимости Азербайджана начался новый этап в жизни православного населения республики. В настоящее время православная община Азербайджана насчитывает около 200 тысяч человек или $2,5 \%$ от всего населения страны [7].

28 декабря 1998 года решением Святейшего Патриарха Московского и всея Руси Алексия II и Священного Синода Русской Православной Церкви была восстановлена Бакинская и Прикаспийская епархия, ставшая 128-й епархией Русской Православной Церкви и архимандрит Александр (Ищеину) стал епископом этой епархии. В состав Бакинской и Прикаспийской епархии вошли православные приходы на территориях Азербайджанской Республики, Республики Дагестан и Чеченской Республики. Епархия насчитывала23 прихода,22 храма, 1 женский монастырь, 5 часовен, 1 молитвенный дом и 2 молитвенные комнаты на территории исправительно-трудовых учреждений, 5 воскресных школ. Решением Священного Синода от 22 марта 2011 года приходы на территории Республики Дагестан и Чеченской Республикивключены в состав Владикавказской и Махачкалинской епархии. А Бакинская епархия объединяет приходы на территории Азербайджанской Республики[9].

В настоящее время в Азербайджане функционируют 5 православных храмов: Кафедральный Собор Святых Жен Мироносиц (Баку), Михайло-Архангельский храм (Баку), Собор Рождества Пресвятой Богородицы (Баку), Александро-Невский храм (Гянджа), Свято-Никольский храм (Хачмас) и Молитвенный дом в честь преподобного Серафима Саровского (Сумгаит). Религиозные дела православного населения в Азербайджане регулируются этими церквями.

В современном Азербайджане православные христиане свободно совершают свои религиозные ритуалы, обряды и традиции, отмечают религиозные праздники. В то же время православная община принимает активное уча- 
стие в общественной жизни азербайджанского общества. Все это стало результатом политикимультикультурализма, проводимаяв Азербайджанской Республике.

\section{ЛИТЕРАТУРА}

Хантингтон С. Столкновение цивилизаций. М., АСТ, 2003, 603 с.

Официальный визит Папы Римского Иоанна Павла П в Азербайджан. Встреча в Бакинском международном аэропорту.https:// azertag.

Закон Азербайджанской Республики о свободе вероисповедания.

https://www.legislationline.org/

Государственный Комитет по Работе с Религиозными Образованиями.http://www.dqdk.gov.az/

AzərbaycanMilliEnsiklopediyası. Bak1, “AzərbaycanMilliEnsiklop ediyası" ElmiMərkəzi, 2007, 884 s.

ARMDTA, f.389, siyahı 4, işlər 10, 48, 57, 111, 123, 154, 155, 200, 247, 249, 280, 321, 405

БакинскаяиАзербайджанскаяепархия. http://baku.eparhia.ru/

BakıXəzərsahiliYeparxiyasınınyaranmasının 10 illiyimünasibətilə "Ruspravoslavkilsəsi" foto-sərgisi.http://www.museumcenter.az/ calendar,269/lang,az/

Бакинская и Прикаспийская епархия. http://www.patriarchia.ru/ $\mathrm{db} / \mathrm{text} / 930706 . h \mathrm{tml}$

\section{PЕЗЮMЕ}

Христианство в Азербайджане имеет древнюю историю, православная церковь играет важную роль в религиозной жизни республики. В 1919 году была создана Бакинская и Прикаспийская епархия, а в 1934 г. советское правительство приняло решение о закрытии этой епархии. Она была восстановлена в 1998 г. и сейчас в Азербайджане функционируют 5 православных храмов. В настоящее время православные христиане Азербайджана свободно совершают свои обряды и традиции, принимают активное участие в общественной жизни республики.

Ключевые слова: Азербайджан, христианство, православие, епархия, храм. 